\title{
Kullanıcı Beklentilerinin Modern Bir Cami Örneği Üzerinden İncelenmesi
}

\author{
Sena IŞIKLAR BENGi' ${ }^{1}$, A. Yağmur TOPRAKLI ${ }^{1}$
}

Öz

Camiler biçimsel özellikleri, kullanım şekilleri, mimarlık tarihindeki önemleri bakımından akademik çalışmalara ve tartışmalara konu olmaktadır. Bu çalışmalar daha çok mimarların biçimsel arayışları ile gündeme gelen tartışmalardır. Mimarlık camiasında birçok mimar ve mimarlık eleştirmeni bu alanda düşüncelerini ifade etmiştir. Öne çıkan görüşlerden biri camilerin yakın çevresini niteleyen merkez yaratması, toplanma mekânı yaratan sosyal, kamusal bir yapı olması, anıt, simge ve işaret değeri üzerinden değerlendirilmesi gerekliliğini savunmaktadır. Cami değerlendirmelerinin çoğunlukla uzmanların biçimsel yaklaşımlarla sürdüğü görülmüştür. Buna karşın her mimari yapıda olduğu gibi sakinlerinin yorumları yapıların eksikliklerinin saptanmasında, iyileştirilmesinde ve mimari tipolojinin geliştirilmesinde önemlidir. Değişen kullanımlar ve dolayısı ile mekânsal dönüşüm kullanıcı yorumlarıyla saptanabilir kılınacaktır. Bu çalışmada Ankara'nın protokol camilerinden Ahmet Hamdi Akseki Cami ele alınmıştır. Caminin değerlendirilmesi kullanım sürecinde değerlendirme yöntemi kapsamında 139 kişilik bir alan çalışmasıyla elde edilmiştir. Cami anıt, simge ve işaret değeri, yakın çevresini niteleyen merkez yaratması, toplanma mekânı yaratan kamusal bir yapı olması, camilerin geçmiş ve güncel kullanımları doğrultusunda incelenmiştir. Böylece yapıların asıl sahibinin kullanıcıları olduğu savıyla, Ahmet Hamdi Akseki Cami'nin eksiklikleri saptanmış, öneriler sunulmuştur. İncelemeleri ve değerlendirmeleri ile bu çalışma, cami tasarımlarındaki literatüre çeşitlilik katan, kullanıcı beklentilerinin önemini vurgulayan bir etki yaratacaktır.

Anahtar Kelimeler: Cami tasarımı, kullanıcı beklentisi, kullanım sürecinde değerlendirme.

\section{Analysis of User Expectations over an Example of a Modern Mosque}

\begin{abstract}
\footnotetext{
${ }^{1}$ Gazi Üniversitesi, Mimarlık Fakültesi, Mimarlık Bölümü, Ankara.

* İlgili yazar/Corresponding author: sena.isiklar@gmail.com

Gönderim Tarihi / Received Date: 18.11.2019

Kabul Tarihi / Accepted Date: 08.06.2020
}

Mosques are subject to academic studies and discussions in terms of their formal characteristics, usage patterns and their importance in architectural history. These studies are mostly debates on the formal search of the architects. Many architects and architectural critics were among the people that express their thoughts in this area. One of the prominent views claims that mosques should create a center that characterizes the immediate surroundings, social and public structure that creates a gathering place, and should be evaluated on the basis of monuments, landmarks and signs. It has been observed that the evaluations of the mosques mostly continue with the formal approaches of the experts. However, as with any architectural building, residents' comments are important in identifying and improving the deficiencies of 
buildings and developing architectural typology. Thus, spatial transformation will be made detectable due to changing uses. Ahmet Hamdi Akseki mosque, one of Ankara's protocol mosques, was examined in this paper. The evaluation of the mosque was obtained through a field study of 139 people within the scope of the post occupancy evaluation. The mosque has been examined in terms of its monuments, symbol and sign value, its central creation which qualifies its immediate surroundings, and its public structure which creates a meeting place in accordance with past and current uses of mosques. Thus, with the claim that the original owners of the buildings were the users, the deficiencies of Ahmet Hamdi Akseki mosque were determined and proposals were presented. This study with its reviews and evaluations it will bring diversity to the literature in mosque designs and emphasizes the importance of user expectations.

Keywords: Mosque design, user expectation, post occupancy evaluation.

\section{KAMUSAL BAĞLAMDA CAMILER}

Camiler mimarların, sanat tarihçilerinin ve ilahiyatçıların odağında bulunan, hem sanat hem de din bilimlerince ele alınmış bir konudur. Secde edilen, cemaatle namaz kılınan yer anlamındaki "mescidül cami" adı zamanla kısaltılarak "cami" olarak anılmaya başlanmıştır (Hasol, 2010: s. 105). Kelimenin etimolojik kökeni "dağınık şeyi toplamak, biriktirmek, birleştirmek, elbise giymek, müellif mürettip'ten gelmektedir. İbadet yeri İslam'ın kendi kimliğine özgüdür. Bu yer, tek başına bir bina değil, sujud'un (secde) yeri anlamına gelmektedir (Longhurst, 2012).

Günümüzde camiler vaaz, hutbe, din öğretimi, cuma, bayram, cenaze ve beş vakit namazın kılınması gibi bedensel ibadetlerin gerçekleştiği yerlerdir. Camilerde mekânlar genellikle bir büyük dua odası, imam (dua lideri) için küçük oda ve hatip (vaiz) için bir yerden oluşmaktadır. Birçok durumda bu bileşenler büyük bir hacimde bulunmaktadır. Ayrıca erkek ve kadın için abdesthane ve tuvaletler (Kurniawan, 2011); büyük camilerde ise, harim, harem, sahın, son cemaat yeri, minare, şadırvan, muvakkithane, imam ve müezzin odaları, musalla taşı gibi birimler ${ }^{2}$ de fonksiyonda yer almaktadır (Hasol, 2010: s. 105).

Dini kullanımlara ek olarak bazı camilerde lojmanlar, çok amaçlı salonlar, açık alanlar, market, kütüphane gibi yan birimler de ana işleve eklendiği görülmektedir. Böylece camilerin sadece ibadet vakitlerinde değil, günün diğer saatlerinde de aktif kullanımını sağlanması amaçlanmaktadır. Geçmişte camilerin külliye yapısı içerisinde yer aldığı bilinmektedir. Bu sebeple 'külliye'nin kısaca açıklanması bu bölümde gerekli görülmüştür.

Külliye, çeşitli fonksiyonel yapı birimlerinin bir arada planlanıp inşa edildiği sosyal kuruluş" (Cantay, 2002), "çevresinde çeşitli sosyal görevi olan binaların düzenlenmesi suretiyle meydana getirilmiş bir binalar kompleksi" (Akozan, 1969) olarak tanımlanmaktadır. Bursa'da Yeşil İmaret (1419), Edirne'de II. Bayezit Külliyesi (1487), Amasya'da II. Bayezit Külliyesi (1486), İstanbul'da II. Bayezit Külliyesi (1501-1506) ve Sultan Selim Külliyesi (1520 - 1523), Lüleburgaz Sokullu Mehmet Paşa heyeti (1549 -

\footnotetext{
${ }^{2}$ Harim: Camilerin ana ibadet mekânı.

Harem: Kadınlara özgü ibadet mekânı.

Sahın: Camilerde üstü büyük kubbe ile örtülü, Mekke'ye yönelen ibadet bölümü.

Son cemaat yeri: Büyük camilerde, cami ile cami avlu arasında, yarı açık, revaklı mekân.

Minare: Camilerde ezan okunan, sela verilen, şerefeli, yüksek ve ince yapı.

Şadırvan: Cami avlularında bulunan, üzeri kubbeli veya açık, su kaynağı içeren birim.

Muvakkithane: Namaz vakti tespit edilen mekân.

Musalla taşı: Camilerin avlusunda, cenaze namazı için ölen kişinin konulduğu eleman.
} 
1570), Payas'ta Sokullu Mehmet Paşa heyeti (1599), İstanbul'da Nuruosmaniye Camii heyeti (1748 -1757) yapı türüne örnek olarak gösterilmektedir (Akozan, 1969). Daha fazla örnek için TDV İslâm Ansiklopedisi'nin 26. cildinde, 542-544 numaralı sayfaların incelenmesi önerilir (Url-1).

Külliyeler bir sosyal merkez olarak cami, medrese, türbe, hastane, aşhane, tabhane, mektep, kütüphane, arasta /çarşı, han/kervansaray, hamam, meşruta binaları, helâlar, muvakkithane ve çeşme-sebil gibi birimleri barındırmaktadır (Akozan, 1969). Birimlerin tamamının külliyede yer alması gerekmemekle birlikte, bu yapılardan bir kaçının bir arada bulunması kompleksin külliye olarak adlandırılması için yeterlidir (Cantay, 2002) Bu birimler Tablo 1'de kısaca aşağıda gruplanarak açıklanmaktadır.

Tablo 1. Külliye birimleri

\begin{tabular}{|c|c|c|}
\hline \multicolumn{2}{|c|}{ Külliye birimleri } & \multirow{2}{*}{$\begin{array}{l}\text { Tanımı } \\
\text { Cami, hutbeler yoluyla toplumu uyarıcı bildiri ve telkinlerin } \\
\text { yapıldığı, kişilerin dini eylemlerini gerçekleştiği bir toplantı yeridir } \\
\text { (Akozan, 1969). }\end{array}$} \\
\hline \multirow[t]{3}{*}{ İbadet } & Cami & \\
\hline & Muvakkihane & $\begin{array}{l}\text { Külliye içinde küçük yapılar olarak görülen muvakkithane, vaktin } \\
\text { tahmini için kullanılmaktadır (Akozan, 1969). }\end{array}$ \\
\hline & $\begin{array}{l}\text { Türbeler, } \\
\text { hazireler, } \\
\text { mezarlıklar }\end{array}$ & $\begin{array}{l}\text { Camiyi inşa eden kişi ve akrabalara ait mezar yerleridir (Akozan, } \\
\text { 1969). }\end{array}$ \\
\hline \multirow[t]{3}{*}{$\begin{array}{l}\text { Eğitim } \\
\text { birimleri }\end{array}$} & Medrese & $\begin{array}{l}\text { Medreseler skolastik öğretimin ileri kademelerini veren bilim } \\
\text { kuruluşlarıdır. Medrese çalışma odalarının yanı sıra öğrencilere } \\
\text { konaklama birimlerini bir bina tipidir (Akozan, 1969). }\end{array}$ \\
\hline & Mektep & $\begin{array}{l}\text { Külliyenin küçük bir binasıdır. Bugünün ilkokuluna denk düşen } \\
\text { mektep, çoğunlukla sibyân mektebi olarak kullanılmaktadır } \\
\text { (Akozan, 1969). Dershane, öğrencilerin ve medrese } \\
\text { görevlilerinin kaldığı birimler ve çeşme, hela gibi temel servis } \\
\text { birimlerini içermektedir (Ramazanoğlu, 2008). }\end{array}$ \\
\hline & Kitaplık & $\begin{array}{l}\text { Medreselerde bulunan öğrencilerin ihtiyacını gidermek üzere } \\
\text { külliye programı içinde yer alan birimlerdir (Akozan, 1969). }\end{array}$ \\
\hline \multirow[t]{2}{*}{$\begin{array}{l}\text { Sosyal } \\
\text { mekânlar }\end{array}$} & Aşhaneler & $\begin{array}{l}\text { Aynı zamanda imaret olarak adlandırılan aşhane yoksullara } \\
\text { yiyecek dağıtmak için kurulmuştur (Ramazanoğlu, 2008). Aynı } \\
\text { zaman burada külliyedeki görevlilere, medreselerdeki } \\
\text { öğrencilere, misafirlere de yemek verilmektedir (Akozan, 1969). }\end{array}$ \\
\hline & Tâbhane & $\begin{array}{l}\text { Bu binalar, külliyenin misafirhaneleri olarak kullanılmakta, } \\
\text { misafirlerin, seyahat edenlerin misafir edildiği yerlerdir (Akozan, } \\
\text { 1969). }\end{array}$ \\
\hline \multirow[t]{3}{*}{$\begin{array}{l}\text { Sıhhi } \\
\text { mekânlar }\end{array}$} & Şifahane & $\begin{array}{l}\text { Hem hastaların tedavi edildiği hastane hem de tıp öğrencilerinin } \\
\text { uygulamalarda bulunduğu birimdir (Ramazanoğlu, 2008). }\end{array}$ \\
\hline & Hamam & $\begin{array}{l}\text { Cami inşaatına başlandığında öncelikle çevresinde yapılan yapı, } \\
\text { hamamdır (Akozan, 1969). Kullanıcıların hamamdan } \\
\text { yararlanmak için ücret ödemesi bu birimin aynı zamanda ticari bir } \\
\text { birim olarak görülme nedenidir (Ramazanoğlu,2008). }\end{array}$ \\
\hline & $\begin{array}{l}\text { Çeşme-Sebil- } \\
\text { Umumi Helalar }\end{array}$ & $\begin{array}{l}\text { Bu birimler çoğunlukla hayır amacıyla inşa edilmekte, abdest } \\
\text { almak için kullanılmaktadır (Ramazanoğlu,2008). }\end{array}$ \\
\hline \multirow[t]{2}{*}{$\begin{array}{l}\text { Ticari } \\
\text { mekânlar }\end{array}$} & Kervansaray & $\begin{array}{l}\text { Seyahat yollarında bulunan kervansaraylardan ayrı düşünülmesi } \\
\text { gereken bu yapılar (Akozan, 1969) bir avlu çevresindeki dükkân, } \\
\text { depo ve odalar ile meydana gelen; kunduracı, nalbant, baytar } \\
\text { gibi görevliler için birimlerin de bulunduğu yapı türüdür } \\
\text { (Ramazanoğlu, 2008). }\end{array}$ \\
\hline & Arasta-Çarşı & $\begin{array}{l}\text { Çarşı veya arasta binaları için külliyeler inşa edilmektedir. } \\
\text { Çarşının külliye içindeki yeri öncelik taşımaktadır (Akozan, 1969). }\end{array}$ \\
\hline
\end{tabular}

Güzer (2009) camileri üç bağlamda ele almaktadır: 
1. Toplanma mekânı yaratan sosyal ve kamusal bir yapı olması,

2. Yakın çevresini niteleyen merkez yaratması,

3. Anıt, simge ve işaret değeri (Güzer, 2009).

\section{Caminin toplanma mekânı yaratan sosyal ve kamusal yönü}

Cami, toplumdaki her bireyin herhangi bir ayırıma gitmeden bir araya geldikleri, kaynaştıkları kutsal bir mekândır. Tarihte ibadet, eğitim, sosyal alan, devletin yönetim merkezi olmasının yanı sıra hastane, depo, kışla, mahkeme, kütüphane gibi işlevler de barındırmıştır (Arpacıoğlu, 2006). Ayrıca, Müslümanların güncel meselelerinin konuşulduğu bir yerdir (Vehbi, 2010).

Geçmişte Osmanlı kentlerinde de kentin merkezinde ticari yapılar, cami ve hamam yer almaktadır. Oluşan yapılı çevre kadın-erkek, genç-yaşlı, köylü-kentli, müslimgayrimüslim her profilden insanın uğradığı ve ihtiyacını karşıladığı mekânı oluşturmuştur (Akar, 2009). Bu durumun örnekleri camilerin külliyeler içinde yer almasıyla görülmektedir. Günümüzde ise, bu durum değişmiştir. Camiler külliyelerden bağımsız ve tekil yapılar olarak hızla gelişen kentte yerini bulmuştur. Bu doğrultuda ise, içerdiği yan fonksiyonları kaybetmiş, çoğunlukla sadece ibadet için mekânı kullanan kısıtlı bir kullanıcı profiline hitap ettiğinden sosyal ve kamusal yönü zayıflamıştır. Bu durumun eksikliği görüldüğünde ise büyük şehirlerde, sergi salonu, kütüphane, ticari birimler gibi yan kullanımları barındıran örnekler görülmeye başlanmıştır.

\section{Camilerin yakın çevresini niteleyen merkez yaratması}

İslam şehirleri incelendiğinde kentin merkezinde caminin bulunduğu, kentin yerleşiminin caminin etrafında gelişen ticaret, medrese ve konut birimleri ile külliyeler oluştuğu görülmektedir. Böylece cami kültürel, sosyal, siyasal ve ekonomik faaliyetlerle bir arada, kentin merkezinde yer almıştır. Bu mekânsal örgütlenme caminin yakın çevresini tanımlayan bir nitelik kurgulandığını göstermektedir. Aynı zamanda kentlerin kimliğinin yaratılmasında katkı sahibidir.

Günümüzde ise, caminin çevresindeki birimlerden ziyade kendi caminin içerdiği yan birimler caminin kültürel, sosyal, siyasal ve ekonomik faaliyetlerle bütünleşmesini amaçlamaktadır. Bu paralellikle T.C. Diyanet İşleri Başkanlığı "Yurt Genelinde Yapılacak Cami Projelerinde Bulunması Gereken Asgari Unsurlar ve Müştemilatlar" Genelgesinde belirtilen kullanımlara ek olarak camilerde yer alabilecek diğer fonksiyonları belirtmiştir (Url-2). Bu birimleri sosyal donatılar ve ticari donatılar olarak iki gruba ayırmak mümkündür:

Camilerin sosyal donatılarından olan,

Derslik: Camiler din eğitimin verildiği, özellikle de küçük yaşta çocukların yaz tatillerinde din eğitimini aldıkları yerlerdir. Bu doğrultuda farklı yaş grupları için özelleşen ergonomik kullanımları ve materyalleri içeren alanlar tasarlanması eğitimin refahı için gereklidir.

Kütüphane: Geleneksel camilerde kütüphane görmek pek mümkün olmasa da T.C. Diyanet İşleri Başkanlığınca müftülüklere genelge ile her camide bir kütüphanenin olmasına ilişkin çalışmalar başlatılmıştır. Böylece toplumun dini bilgilerini doğrudan 
kaynaklardan elde etmesine, dini bilgileri doğru kaynaklardan okuyarak elde etme alışkanlığı kazandırılmasına imkân tanınacaktır.

Nikâh ve düğün merasim alanı: Nikâh iki bireyin beraberliğini duyurduğu bir protokoldür. Günümüzde resmi nikâhlarını yapan çiftler, camilere imam nikâhı için başvurmaktadır. Bu doğrultuda camilere bu eylemin gerçekleşebileceği bir mekân yerleştirildiğinde, camiye yeni bir sosyal işlev katılacak, mutlu günün tebrikleri bu alanda gerçekleştirilebilecektir. Böylece kişiler camiyi yeni bir anlamla daha adlandıracaktır.

Taziye evi: Camilerde cenaze namazları düzenlenmektedir. Bu ibadetin devamı olarak, vefat eden kişinin yakınlarının taziyeleri kabul edeceği, merhumun arkasından dua okunacak taziye mekânlarının eklenmesi caminin mevcut fonksiyonlarından birini tamamlayacaktır.

Aile danışmanlık birimleri: T.C. Diyanet İşleri Başkanlığınca oluşturulan Aile ve Dini Rehberlik Bürolarının camilere taşınmasıyla cemaatin bu birimlere erişebilirliği artacak ve sağlıklı aile ilişkileri kurulmasının önü açılacaktır.

Aş evi: Yoksulların karnını doyurduğu yer olarak bilinen aşeviler cami bünyesinde organize olacak şekilde camiye yeni bir mekân eklenebilir. Bu uygulama devlet eliyle gerçekleşeceği gibi gönüllü kimselerin katkılarıyla da zenginleşebilir. Bu sayede daha çok yoksulun kolaylıkla ulaşabildiği camilerde paylaşma, mutlu etme, aracı olma, başkasının yaşamını sürdürmesine yardımcı olma gibi manevi işlevler de gerçekleşecektir.

Tuvalet, abdest ve lavabo alanları: Bu birimlerin camilerdeki varlığı kesin olarak görülmekle birlikte cemaatin konfor koşullarını artıran ve cami etrafında bulunan diğer kullanıcıların da intiyaçlarını gidermesi bakımından cami inşaatlarında zorunlu fonksiyon olarak belirtilmelidir.

Kurban kesim alanı: Müslümanların yılda bir kez sünnet veya vacip bir ibadet olarak büyük ya da küçükbaş hayvanı kesmesi ve intiyaç sahipleriyle paylaşması üzere ayrılan alanlar kurban kesim alanları olarak adlandırımaktadır. Bu alanların cami bünyesinde yer alması ibadetin dini hükümlülüklere göre yapılması olanağını çoğaltacaktır.

Açık alan kullanımları (çocuk oyun alanları, spor alanları, yeşil peyzaj alanları, meydan olarak avlu kullanımı): Camiler kamusal işlevleri olan topluma hizmet eden yapılar olarak görülmektedir. Bu bağlamda, camiler farklı kullanıcı gruplarının sosyal intiyaçlarını karşılayacak şekilde güncellenmelidir. Bu bağlamda yorumlanabilecek ilk mekân caminin avlusu olarak düşünülmektedir. Avlu kullanımının çocuk oyun alanları, spor alanları, yeşil peyzaj alanları, meydan olarak kullanımı caminin içerdiği fonksiyonları zenginleştirecek müdahaleler olarak görülmektedir.

Camilerin ticari donatılarından olan,

Satış ve ticaret birimleri: Manevi bir işlevin maddi bir işlev ile anılması çokça tartışılan bir konudur. Yurtdışından örnekler incelendiğinde camilerde ticarethanelerin yer almadığı görülmektedir. Ülkemizde cami intiyaçlarının giderileceği bir fon olmadığından dolayı bu tür çözümlere gidilen örnekler görülmektedir. Bu noktada gündeme alınması gereken hangi tür ticari birimlerin cami bünyesinde bulunacağıdır. İslam dinince uygun görülmeyen faaliyetlerin gerçekleştiği, yasaklanan ürünlerin satışının yapıldığı 
ticarethanelerin camilerle planlanmaması önerilmektedir. Örneğin alkol, sigara ve ahlaka uygun olmayan maddelerin satışı bu ticarethanelerden sağlanmamalıdır. Bunun yanında cami kullanıcılarının ihtiyaçlarını karşılayacak market veya kitap satışı birimleri bu alanda bulunabilir.

Modern camilere eklenebilecek eğitim, sosyal, sıhhi ve ticari birimlerin geleneksel cami kurgularında hangi birimlere denk geldiği ise Tablo 2'de gösterilmektedir.

Tablo 2. Cami birimleri

\begin{tabular}{lll}
\hline & $\begin{array}{l}\text { Geleneksel cami çevre } \\
\text { birimleri }\end{array}$ & $\begin{array}{l}\text { Modern cami için önerilen } \\
\text { birimler }\end{array}$ \\
\hline Eğitim birimleri & Medrese, mektep & Derslik \\
\cline { 2 - 3 } & Kitaplık & Kütüphane \\
\hline Sosyal birimler & Aşhaneler & Aş evi \\
\cline { 2 - 3 } & Tâbhane & - \\
\cline { 2 - 3 } & - & Nikâh ve düğün merasim alanı \\
\cline { 2 - 3 } & - & Taziye evi \\
\hline Sıhhi birimler & - & Aile danışmanlık birimleri \\
\cline { 2 - 3 } & - & Kurban kesim alanı \\
\hline Ticari birimler & Kervansaray, arasta-çarşı & Açık alan kullanımları \\
\hline
\end{tabular}

\section{Camilerin anıt, simge ve ișaret değeri}

İslam'ın ibadet yerinin dinin kimliğine özgü olduğu belirtilmektedir (Longhurst, 2012). Camiler, ibadetin yeryüzündeki temsili olarak görülmektedir. Bu temsilde caminin mimari elemanlarının önemi vardır. Örneğin kubbenin sembolikliği geometrisinden kaynaklanmaktadır. Dairesel hacim bütünleşme hissi katmaktadır (Arpacıoğlu, 2006).

Camilerin, toplum için sembolik değeri olmasının yanı sıra devlet tarafından da ideolojik yaklaşımlarla kullanıldığı görülmüştür. Geçmişte Kufe, Basra ve Fustat gibi ordugâh şehirlerdeki Cuma mescitleri halifelerin, devlet başkanlığına geldiklerinde biatlarını aldığı yer olmuştur. Benzer olarak, valiler merkez camisinde halkın konuşmasını yaparak görevlerine başlamışlardır. Ayrıca fetihleri organize etmek amacıyla kullanılmış; savaşlarla ilgili kararlar burada alınmıştır (Demirci, 2003). Milli mücadele zamanlarında Atatürk de Kurtuluş Savaşı'nın kazanılmasında camilerdeki din görevlilerinin halk üzerindeki etkisinden yararlanmıştır (Yavuzer, 2008).

Uzmanlarca camilerin anıt, simge ve işaret değeri hakkında yapılan tartışmalar çoğunlukla caminin üst örtüsü olan kubbe çevresindedir. Altun'un aktarımına göre camilerde kubbe kullanımı çok eskiye dayanmaktadır. Uygur yapılarında kubbe elemanının Türk üçgenleriyle kullanımı görülmektedir (Altun, 1988: s. 32,93). Türk İslam devletlerinde ise, yapılarında kubbe elemanının Türk üçgenleriyle kullanımı Karahanlılar'a dayanmaktadır. Ayrıca bu uygulama Büyük Selçuklular'da, İran'da Artuklular'da, Anadolu'da hatta Kahire'de yer alan camilerde de görülmüştür (Aslanapa, 1972). Artuklu, Danişmendli, Saltuklu, Mengücekli, Anadolu Selçuklu dönemlerinde kubbesiz camiler inşa edildiği görülse de çoğunlukla gelişmiş örneklerini sergilemiştir (Aslanapa, 1973). Osmanlı'da Mimar Sinan'ın Mihrimah Sultan Camisi (1540-1548), Şehzade Camisi (1543-1548), Süleymaniye Camisi'nde (1550-1557), Selimiye Camisi (1569-1575), Tophane Kılıç Ali Paşa Camisi (1580) gibi eserlerinde, kubbe kullanımının gelişmiş biçimlenişlerini görmek mümkündür. 

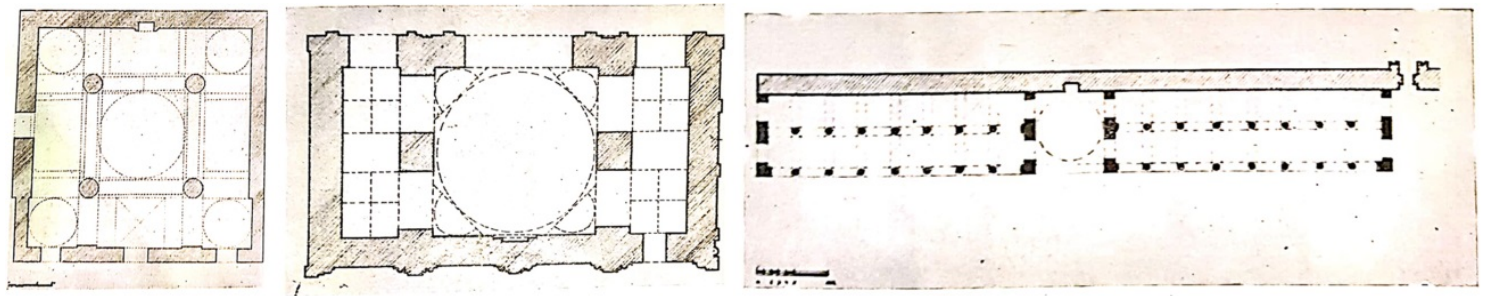

Şekil 1. Hazer Cami, Talhatan Baba, Leşkeri Bazar Ulu Cami planları (Aslanapa, 1972)

Günümüzde camilerde kubbe kullanımı devam etmektedir. Kubbe camilerin ayrılmaz bir parçası olarak anılmaktadır. Buna karşın camilerdeki kubbe kullanımını fonksiyonel ve maliyet bakımından yanlış bir tercih olduğunu düşünenler bulunmaktadır. Behruz Çinici, Uğur Tanyeli, Turgut Cansever gibi Türkiye'nin mimarlık söylemini etkileyen önemli isimler bu konuda yorumlarda bulunmuşlardır (Url-3 ve 4).

"Tasarım ilkeleri açısından kuşkusuz yenilikçi tipolojiler önemli. Kare taban yapıp üzerine kubbe koyuyorsunuz, Neden? İslam başını göğe kaldırmaz ki..." Behruz Çinici (Url-3).

Kubbe caminin sembolik yönünü açığa çıkarın önemli yapı elemanlarından biridir. Güncel cami tasarımlarında kubbe ile ilgili orijinal çalışmaların olduğu izlenmektedir (Bkz. Şekil 2). Bu çalışmalar yapı türüne çeşitlilik katmasına rağmen, caminin anıt, simge ve işaret değerini, cami denilince akla gelen toplumsal belleği zayıflatmaktadır.
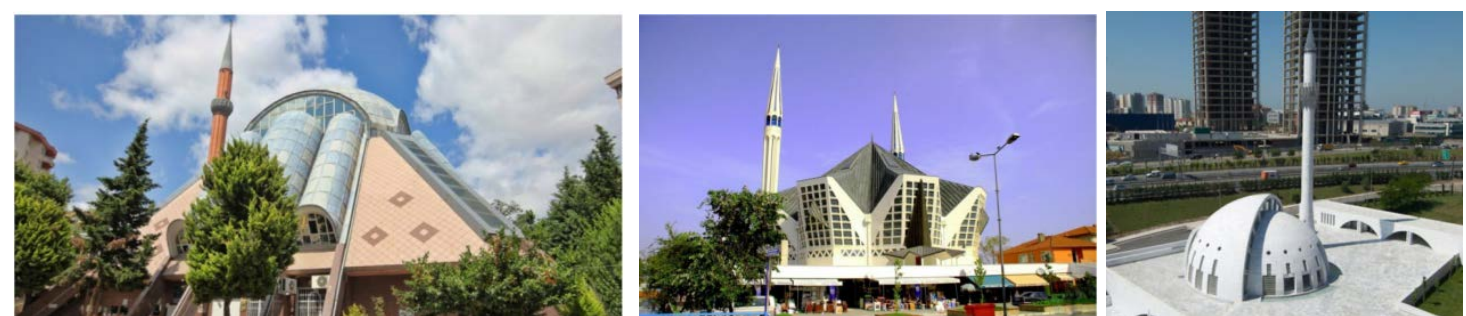

Şekil 2. İstanbul Modern Mehmet Çavuş Cami, Düzce Akçakoca Merkez Cami, İstanbul Yeşil Vadi Camii (Url-5 ve 6)

Cami tartışmaları mimarlık camiasını meşgul ederken, kullanıcı unutulan bir aktör olmaktadır. Atlı'ya göre camiyi ibadet için kullanan, onu yaşayan kitle ve onu daha çok bir nostalji unsuru olarak gören, camiyi izleyen iki kitlenin beklentilerinin aynı olamayacağı belirtilmelidir (Atı, 2016). Çalışmada bu düşünceden hareketle 2013 yılında kullanıma açılan, Ahmet Hamdi Akseki Cami kullanıcı yorumları üzerinden incelenmiştir. Böylelikle camilerde kullanıcı beklentilerinin önemini aktaran akademik metinlerin çoğaltılması ve cami tasarımı çalışmalarının çeşitlendirilmesi amaçlanmıştır. 


\section{AHMET HAMDi AKSEKI CAMI ÖRNEĞINDE KULLANICI BEKLENTILERI}
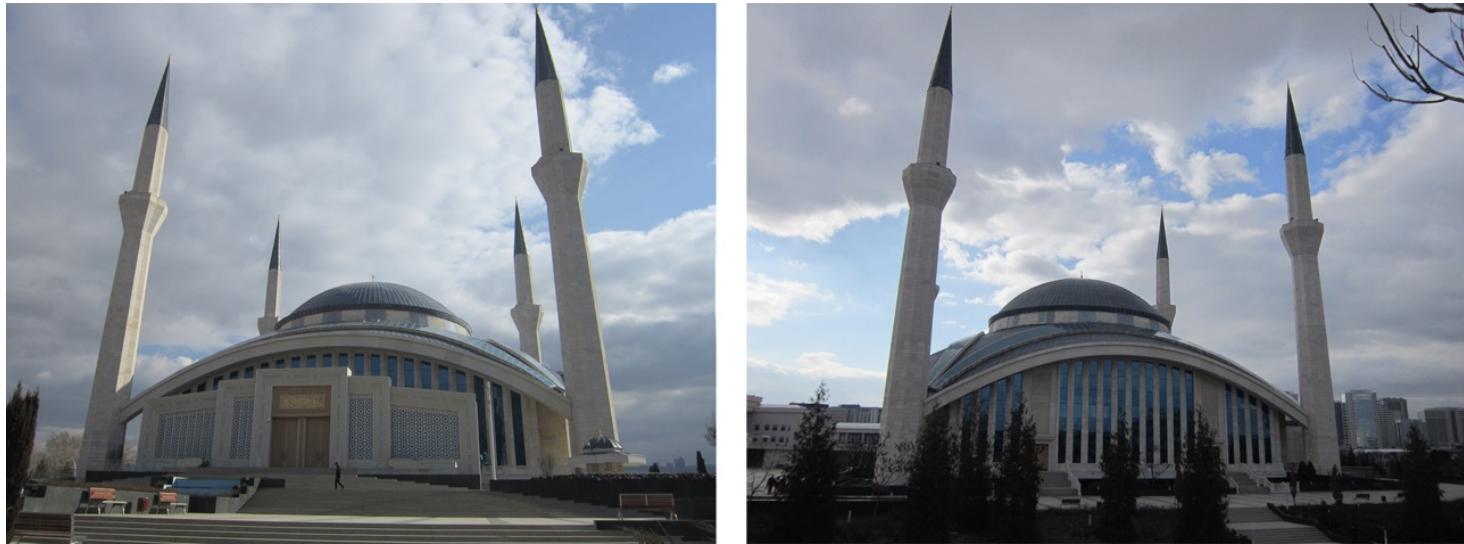

Şekil 3. Ahmet Hamdi Akseki Cami (Fot: Yazar arşivi)

Ahmet Hamdi Akseki Cami 2013 yılından beri kullanımda olan, Ankara'nın Çankaya ilçesinde, TC Tarım ve Orman Bakanlığı, Danıştay, TC Diyanet İşleri Başkanlığı, TC Gümrük ve Ticaret Bakanlığı, Kamu hastaneleri Genel Müdürlüğü ve Şehir Hastaneleri, Ortadoğu Teknik Üniversitesi gibi önemli devlet yapılarının komşuluğunda yer alan, çoğunlukla protokole hizmet eden camidir (Şekil 4). Ankara-Eskişehir yolu üzerinde bulunan cami dolmuş, metro gibi toplu taşıma noktalarına yakınlığı ile erişilebilir bir alanda konumlanmaktadır.

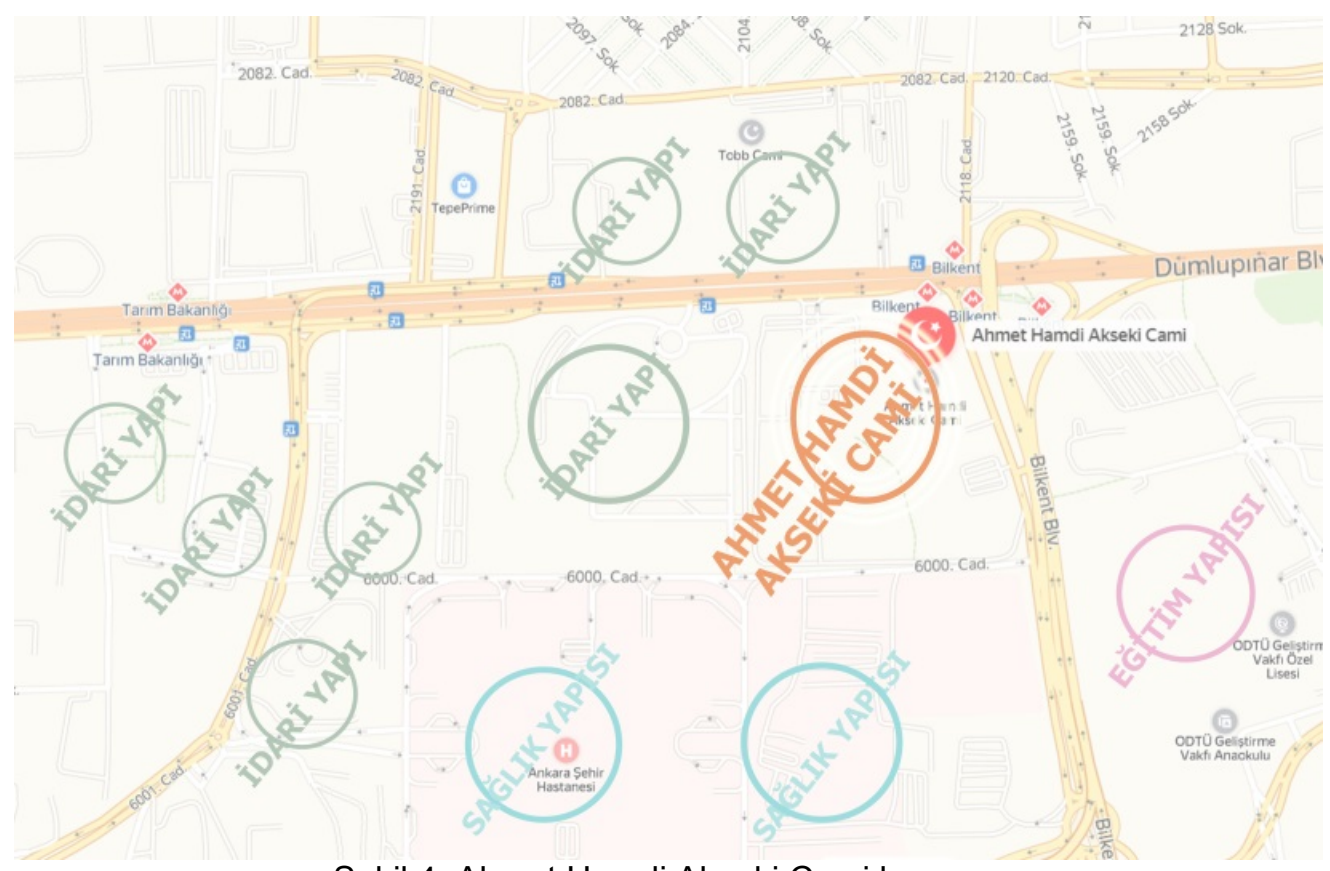

Şekil 4. Ahmet Hamdi Akseki Cami konumu

Ahmet Hamdi Akseki Cami Ender İnşaat tarafından neoklasik tarzda tasarlanmış projedir. Cami, $80.000 \mathrm{~m}^{2}$ kapalı alan, $20.618 \mathrm{~m}^{2}$ avlu, $11.087 \mathrm{~m}^{2}$ peyzaj alanından oluşmaktadır. İçerisinde 1860 araçlık kapalı otopark, depo alanları, stüdyo, gasilhane, umumi hela, harim alanı, yeşil alanlar, oturma alanları, süs havuzları, şelale ve şadırvan bulunmaktadır. Kuzey cephesinde iki, doğu ve batı cephelerinde de iki adet girişi bulunan camide 4 adet merdiven ve 6 adet asansör ve yürüyen merdivenle erişim sağlanmaktadır. 33 metre çapında ana kubbesi bulunan camide Selçuklu desenini esas 
alan Selçuklu yıldızı, rölyefli taş çini, füzyon cam, sedef kakma ve kündekâri gibi geleneksel sanatlara ait motifler bulunmaktadır. Marmara mermeri, altın varak gibi malzemeler (Şekil 6) kullanılmıştır. Tasarım aşamasında Ankara, Erciyes, Gazi ve ODTÜ Üniversitelerinden konusunda uzman danışmanlardan destek alınmıştır (Url-7).

Camide kubbe kullanımının Osmanlı ve Selçuklu mimarisinden izler taşıyan geleneksel tutumun aksine farklılaştığı görülmektedir. Buna ek olarak camide bulunan kapalı otopark, Türkiye Diyanet Vakfı sergi salonu, Kitapkahve Gençlik Çalışmaları, Diyanet Radyo gibi birimler (Şekil 8), geleneksel cami modelinden aykırılıklar içerdiğini göstermektedir.
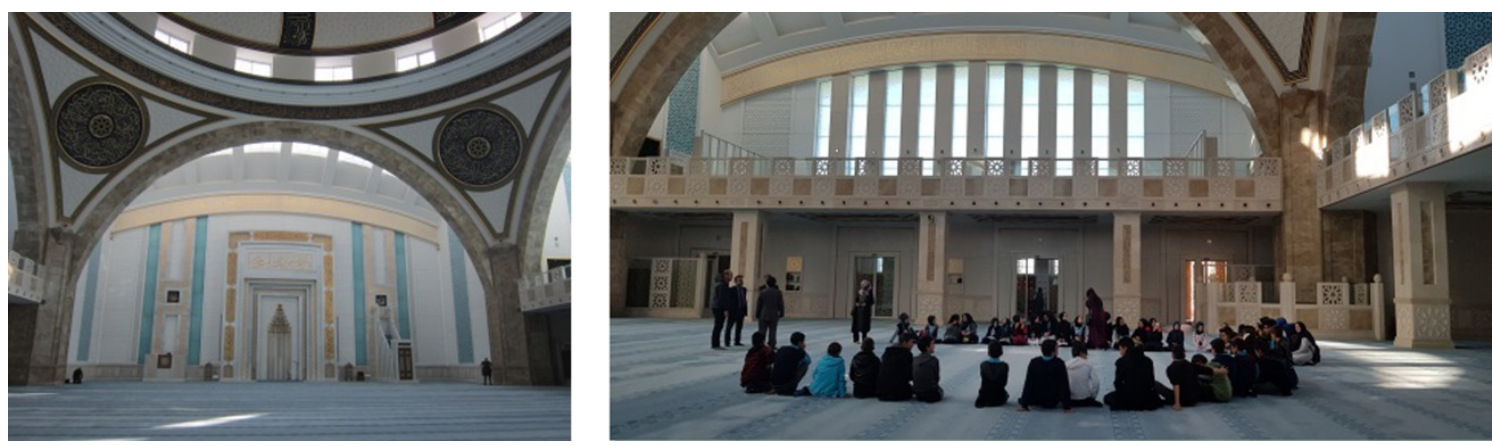

Şekil 5. Harim (Camilerin ana ibadet mekânı) görselleri (Fot: Yazar arşivi)

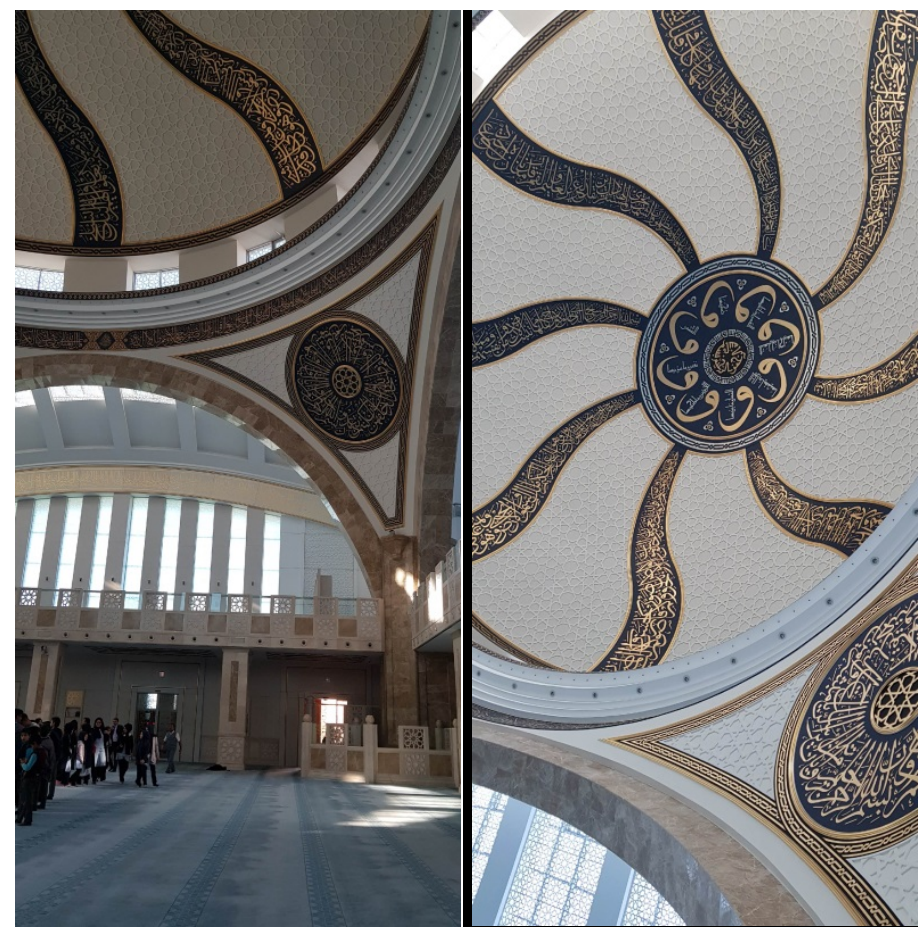

Şekil 6. Camide altın varak kullanımı-1 (Fot: Yazar arşivi) 

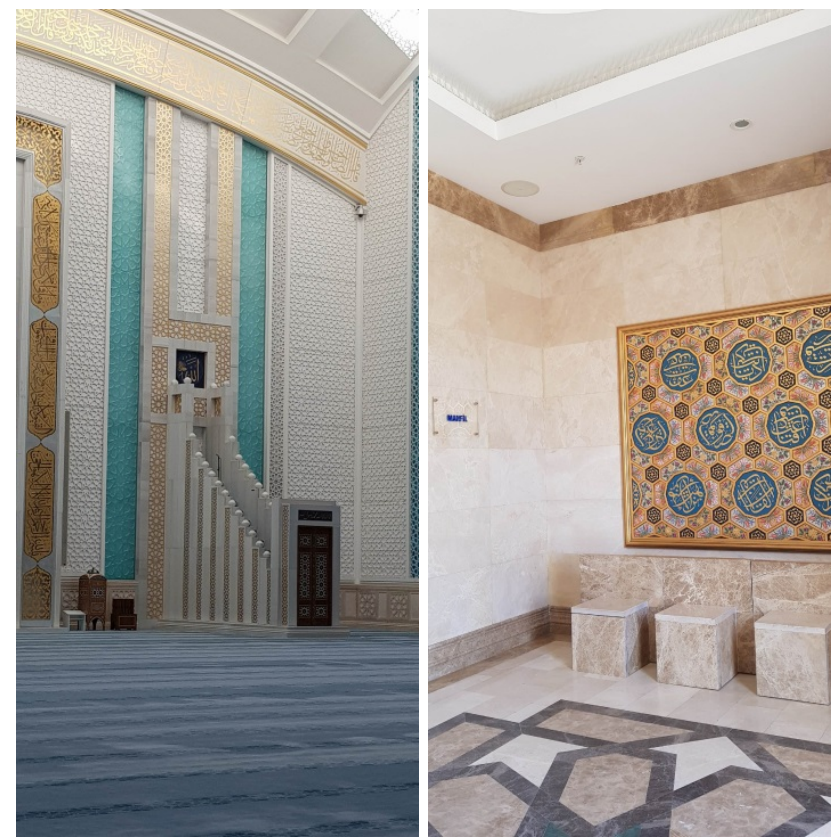

Şekil 7. Camide altın varak kullanımı-2 (Fot: Yazar arşivi)

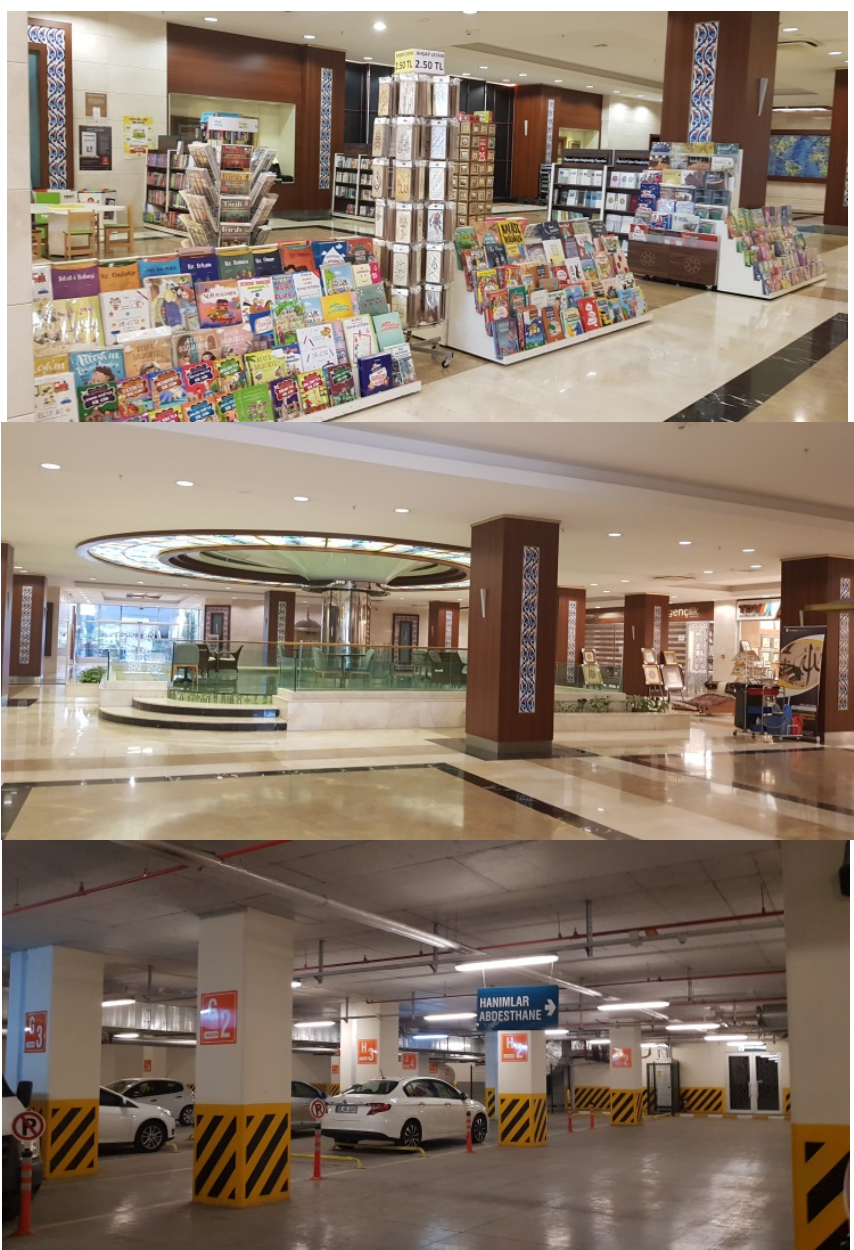

Şekil 8. Caminin diğer kullanımlarına dair görseller (Fot: Yazar arşivi) 

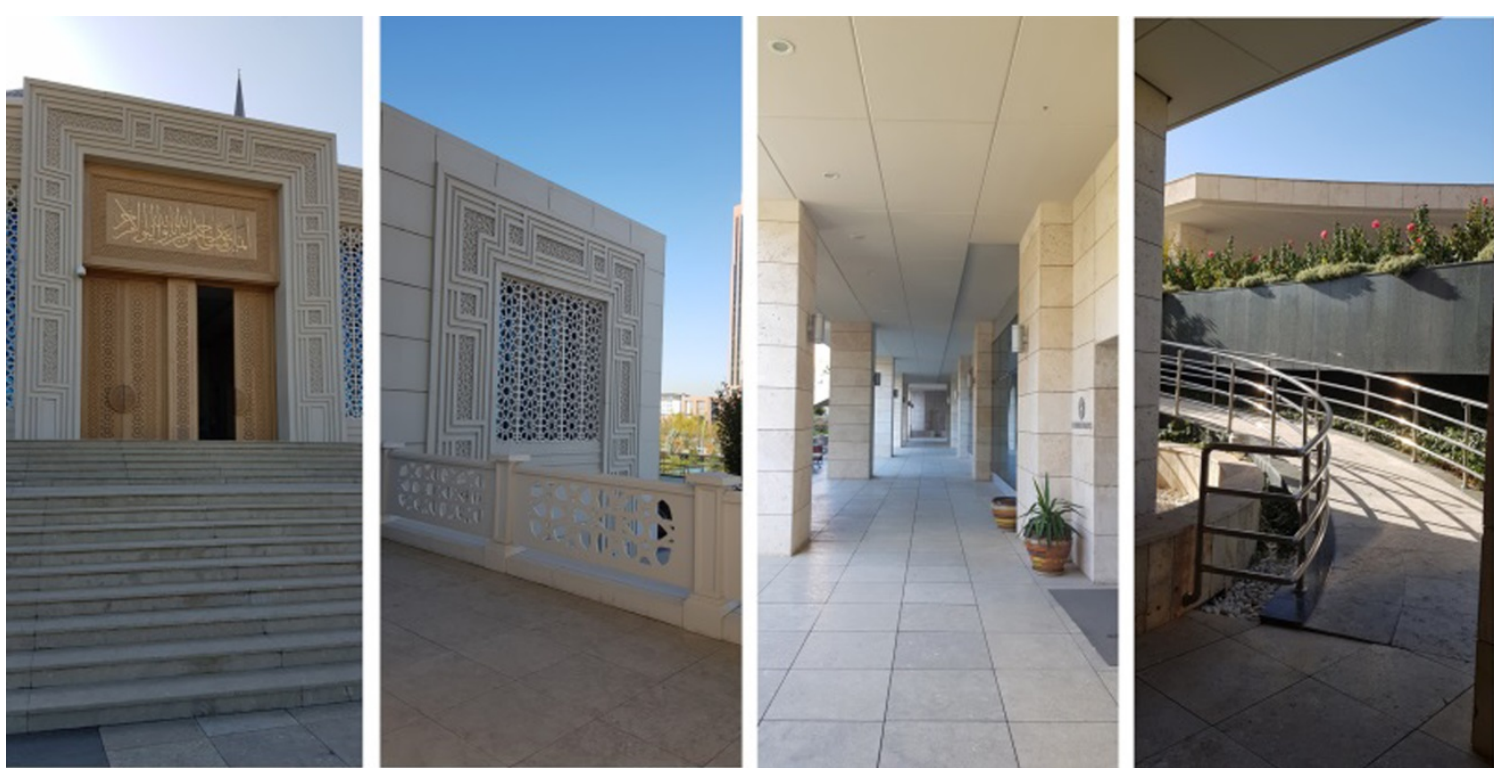

Şekil 9. Caminin dış mekân detaylarından örnekler (Fot: Yazar arşivi)

Cami kullanıcılarının cami hakkında görüşlerinin elde edilmesi için Gazi Üniversitesi ve T.C. Diyanet İşleri Başkanlığı arasında gerçekleştirilen "Cami Planlama ve Tasarımı" Ar-ge projesi kapsamında Aralık 2018'de Diyanet İşleri Başkanlığı personelinden 139 kişiye caminin genel mimari özelliklerini ve caminin kullanım potansiyellerini değerlendirmeye yönelik likert ölçeğinde puanlama sisteminden oluşan (1 en az puan, 5 en yüksek puan olmak üzere) 15 soru yöneltilmiştir. Katılımcılardan bir hafta boyunca toplanan cevapların değerlendirmesi ise SPSS programı tanımlayıcı test aracılığıyla elde edilmiştir.

Tablo 3. Genel mimari özelliklerin değerlendirilmesi

\begin{tabular}{l|l|l} 
& Ortalama & St. Sapma \\
\hline Caminin cadde üzerinden görünürlüğü & 4,32 &, 986 \\
\hline Caminin avlu düzenlemesi & 3,81 & 1,146 \\
\hline İbadet alanının büyüklüğü & 4,71 &, 583 \\
\hline İbadet alanından avluya erişim & 4,53 &, 715 \\
\hline Cami dış görünümünün estetiği & 4,37 &, 828 \\
\hline Cami iç görünümünün estetiği & 4,52 &, 802 \\
\hline Süslemelerdeki motiflerin camiye uygunluğu & 4,39 &, 944 \\
\hline Süslemelerdeki renklerin birbiri ile uyumu & 4,47 &, 819 \\
\hline
\end{tabular}

Mekânın fiziksel özellikleri bireylerin alanı kullanım biçimlerini, kullanım sıklığını belirleyen önemli bir girdi olarak görüldüğünden katılımcılardan Ahmet Hamdi Akseki Cami'nin mimari özelliklerini değerlendirmeleri istenmiştir (Tablo 3). Elde edilen cevaplar sırasıyla ibadet alanının büyüklüğü (puan ort. 4,71), ibadet alanından avluya erişim (puan ort. 4,53), cami iç görünümünün estetiği (puan ort. 4,52), en yüksek puanları alan cevaplar olmuştur. Buna karşın caminin avlu düzenlemesi katılımcılara yöneltilen unsurlar arasında en az puanı alan (puan ort. 3,81) mimari unsur olarak görülmüştür.

Ankette katılımcılara caminin genel mimari özelliklerine dair şikâyetlerin olup olmadığı sorulmuştur.

Genel mimari mekân şikâyetleri,

- Mimarisinin kiliselerden etkilenmiş olduğunun düşünülmesi, 
- Osmanlı mimarisinden esinlenilmemiş olması,

- Cam kaplamaların fazlalığı,

- Minaresinin kısa bulunması.

Açık alan şikâyetleri,

- Avlu taşlarının dayanıksız olması,

- Cami avlusunda gölgelik bir alan ve ağaçlandırma bulunmaması,

- Cami avlusunun buluşma oturma eylemleri için kullanılamaması katılımcılardan cevap olarak alınmıştır.

Tablo 4. Camiye dair hissiyatlar

\begin{tabular}{l|l|l} 
& Ortalama & St. Sapma \\
\hline Etkileyici & 4,14 &, 864 \\
\hline Konforlu & 4,35 &, 814 \\
\hline Güvenli & 4,35 &, 770 \\
\hline Huzur verici & 4,33 &, 774 \\
\hline
\end{tabular}

Hamdi Akseki Cami'nin katılımcılara anımsattığı hislerden etkileyici, konforlu, güvenli ve huzur verici düşük ve yakın standart sapmalarla, 5 üzerinden 4 ve üstü olarak ortalama olarak cevaplandırılmıştır. Katıımcılar camiyi çoğunlukla etkileyici, konforlu, güvenli ve huzur verici (4 üstü ortalama ile) bulduğunu belirtmiştir (Tablo 4).

Tablo 5. Eklenebilecek potansiyel kullanımların değerlendirilmesi

\begin{tabular}{l|l|l} 
& Ortalama & St. Sapma \\
\hline Çocuklar için kreş & 3,43 & 1,593 \\
\hline Öğrenciler için kurs & 3,86 & 1,316 \\
\hline Kadınlar için lokal & 3,11 & 1,545 \\
\hline Aileler için danışma birimi & 3,56 & 1,465 \\
\hline Yaşlılar için yardım evi & 3,21 & 1,525 \\
\hline Muhtaçlar için aşevi & 3,62 & 1,539 \\
\hline Alışveriş yapılabilecek ticari birimler & 2,81 & 1,540 \\
\hline
\end{tabular}

Camiye eklenebilecek fonksiyonlar kullanıcılara sorulmuştur (Tablo 5). Birimlerin gerekliliğinde "öğrenciler için kurs" en gerekli görülürken (puan ort. 3,86), "muhtaçlar için aşevi" (puan ort. 3,62) öğrenci kurslarını takip etmiştir. "Aileler için danışma birimi" (puan ort. 3,56 ) "çocuklar için kreş" (puan ort. 3,43) cevapları yüksek ortalama alan diğer cevaplar olarak görülmüştür. "Alışveriş yapılabilecek ticari birimler" en az gerekli görülen (puan ort. 2,81) yan kullanım olarak cevaplanmıştır. Gençlere yönelik DíB kontrolünde okuma atölyeleri, gençler için spor alanları, görevlilerle sohbet edilebilecek ortam, kütüphane, Hadis, Fıkıh, Tefsir Dersleri düzenlenmesi, alışveriş yapılabilecek veya yemek yenilebilecek bir yer bulunmasının gerektiği ek yanıt olarak alınmıştır.

\section{DEĞERLENDIRME VE SONUÇ}

Cami, Müslümanların kültür, inanç, ibadet eylemlerinin mekânsal karşılığıdır. Geleneksel camilerin külliye içinde yer aldığı görülmektedir. Külliyeler ise, dini, eğitim, sosyal, sıhhi ve ticari birimleri ile bir merkez niteliği taşımaktadır. Bu merkezler kentlilerde aidiyet geliştirmek, birbirleri ile iletişim halinde olmak, eğitim alıp kişinin kendini geliştirmesi, insani intiyaçların karşılanması gibi iyileştirici etkilerde bulunmuştur. Fakat cami yapı türünün güncel örnekleri incelendiğinde birimlerin bir merkez içinde değil, daha çok tekil örnekler içinde kentte yer aldığı izlenmiştir. Kentlerin hızla gelişmesi, çok merkezli yapılar haline bürünmesi, merkez içinde yer alan birimlerin zaman içinde farklı mekânsal çözümlerle kentte yer alması gibi gelişmelerin 
zaman içinde görülen bu değişimdeki payı ayrıca vurgulanmalıdır. Bu etkenler, camilerin çevresinde yer alan destek fonksiyonları kaybetmelerine, sadece ibadet saatlerinde kullanılan birer mekân haline gelmelerine neden olmuştur. Dolayısı ile kullanıcı profili de kısıtlanmıştır.

Belirtilen eksiklikler anlaşıldığında, camileri yan işlevleri de barındıracak şekilde kurgulayan örnekler inşa edilmiştir. Bu örneklerden biri olan Ahmet Hamdi Akseki Cami yerinde gözlemler ve kullanıcı anketi ile incelenmiştir. Caminin külliyelerde yer alan bazı sosyal donatıları da bünyesinde barındırarak, genç-yaşlı, her kesim ve ihtiyaçtan kullanıcıları kucaklayarak, kent hayatına katılmayı arzulayan bir yaklaşımla tasarlandığı anlaşılmıştır. Fakat kullanıcıları ile yapılan görüşmelerde, kişilerin camiden mekânsal, işlevsel, fonksiyonel ya da görsel olarak karşılanamayan beklentileri olduğu anlaşılmıştır. Buna göre Ahmet Hamdi Akseki Cami,

Toplanma mekânı yaratan sosyal, kamusal bir yapı üzerinden ele alındığında,

Açık kent alanları toplumun yaşamının sergilendiği, kişilerin birbiri ile diyalog kurarak ilişki kurması için gerekli bir sahnedir. Bu doğrultuda camilerin avlu tasarımı, cami iç mekânı ile birlikte tasarlanması ve camilerde açık alan kullanımının desteklenmesinin gerekliliğinin de cami tasarımlarında düşünülmesi gereken başka bir önemli girdidir. Ayrıca mekâna eklenen, çevre ile uyumlu yan fonksiyonların da caminin kamusal bir yer olma etkisini artıracağı unutulmamalıdır. Külliye içinde bulunan ve cami kullanımını da destekleyen yapılardan eğitim birimleri ve muhtaçlar için aşevinin geçmiş kullanımları ve camilerin güncel kullanıcılarının talebi doğrultusunda camilere eklenmesinin caminin sosyal ve kamusal bir mekân olma niteliğini destekleyeceği vurgulanmalıdır.

Yakın çevresini niteleyen merkez yaratması üzerinden ele alındığında,

Bir yapının çevresini niteleyen merkez yaratması içerdiği fonksiyonların çevre faaliyetleriyle uyumu ve onları beslemesi ile sağlanabilir. Geçmişte bu birimler diğer dini birimler, eğitim, sosyal, sıhhi ve ticari birimlerle sağlanmaktaydı. Günümüzde ise, Ahmet Hamdi Akseki Cami bu kullanımlardan bazılarını bünyesinde barındırmakta olduğu görülmekte, buna karşın anket katılımcılarının öğrenciler için kurs, muhtaçlar için aşevi, aileler için danışma birimi, çocuklar için kreş arzuları kullanıcıların sosyal faaliyetlere verdiği önemi göstermektedir. Ek olarak okuma atölyeleri, sohbet edilebilecek ortam, kütüphane ve spor alanları cemaat tarafından önerilmiştir. Kullanıcıların camilerde sosyal ilişkileri kuvvetlendiren, yardımlaşma ve öğrenme eylemlerini pekiştiren faaliyetleri ticari mekânlardan ziyade görmek istedikleri açıktır. Cami cemaatinin bölgesel ihtiyacı ve beklentilerini giderecek, sosyal kullanım olanakları taşıyan, dayanışma ve yardımlaşmayı kapsayan yeni faaliyetler eklenmesi kullanıcıları tarafından sahiplenmeyi artırıcı bir müdahale olabilir.

Camilerin anıt, simge ve işaret değeri üzerinden ele alındığında,

İbadetle arzulanan ruhsal ferahlığa erişme ibadetin gerçekleştiği alandaki mekânsal koşullarla desteklenmelidir. Caminin bulunduğu çevre ile olan ilişkisi, kullanım rahatığı, yan birimlerin varlığı gibi unsurlar cemaatin camiye dair beslediği hislerin gelişiminde önemli bir girdi oluşturmaktadır. Bu sebeple caminin asıl sahibi olan kullanıcılara Ahmet Hamdi Akseki Cami'nin mekânda izlenen sembolik niteliklerine dair sorular yöneltilmiştir. Cami kullanıcılarının geçmiş dönem camilerinde yer alan sosyal ve kamusal mekânsal nitelikleri günümüzde de görmeyi arzulaması ve ek yorumları caminin geleneksel örneklerine duyulan özlemi açığa çıkartmaktadır. Ahmet Hamdi 
Akseki Cami örneğinde kullanıcıların yapının kiliselerden etkilenmiş olduğunu düşünmesi, Osmanlı mimarisinden esinlenilmemiş olmasını sorun olarak görmesi, minaresinin kısa bulunması gibi yorumlar cemaatin cami mimarisinde geleneksel izleri görmek istediğini, imgelerinde yer alan cami görünümünün devamını arzuladıklarını göstermektedir. Bu noktada "kubbe olmalı mı yoksa olmamalı mı sorusu?" kullanıcıların camilerde arzuladığı görünüm dikkate alınarak "kubbe nasıl olmalı?" şekline dönüşmelidir.

Caminin anıt, simge ve işaret değerini oluşturan estetik değerlerinin mekâna dair beslenen hisler üzerinde etkisi olduğu düşünülerek kullanıcılara mekâna dair hisleri sorulduğunda güzel duygular estetik değerler için yapılan kötü durumlarla çelişmiştir. Bu noktada kullanıcıların camilerin inşa edilmesinde rol sahibi bir kurumun kullanıcıları olması sebebiyle cevapların çarpıtılmış olma intimali de düşünülmelidir. Bu sav tartışma havuzuna katılacak başka cami analizleri ile yeniden denenmelidir.

$\mathrm{Bu}$ çalışma ile camilerin mekânsal niteliklerinin zaman içinde dönüşümü ve kullanıcıların dönüşüm sonuçlarında meydana gelen camilerin güncel bir örneği hakkında arzuları sunulmuştur. Ele alınan konunun camilerin semantik değerinin geleceğe taşınmasında etkili olacağı düşünülmektedir. Bu noktada unutulmaması gereken yapılı çevrelerin inşa edildikten sonra kullanıcısına ait olduğudur. Yapı kullanıcısının varlığı ile anlam kazanır ve gelişir. Her yapı türünde olduğu gibi camilerin varlığı, kullanıcının varlığı ve mekânın içinde gerçekleşen eylemler ile sürdürülebilir. Kullanıcının mekândan memnuniyetini yükseltmek mimarların, idari otoritelerin gündemine alınmalıdır. Öncelikle kullanıcıların yapıdan beklentilerinin ne olabileceği saptanmalı, yapıların eksikleri belirlenmelidir. Düzenlemelerle hem mevcut camilerin memnuniyet düzeyleri artırılmalı hem de yapılacak olan tasarımlara bir bilgi havuzu oluşturulmalıdır. Böylece sahiplenen, aidiyet duyulan ibadet mekânları elde etmek için bir adım atılacaktır.

\section{KAYNAKLAR}

Akar, T., Osmanlı Kentinde Ticari Mekânlar: Bedesten-Han-Arasta-Çarşı Mekânları Literatür Değerlendirmesi. Türkiye Araştırmaları Literatür Dergisi, 2009, (13), ss. 267292.

Akozan, F., "Türk Külliyeleri”, Vakıflar Dergisi, VIII, Ankara 1969, ss. 303-308.

Altun, A., Sinan Öncesi Mimari Tasarım, Mimarbaşı Koca Sinan Yaşadığı Çağ Ve Eserleri 1 (içinde). İstanbul: T.C. Başbakanlık Vakıflar Genel Müdürlüğü, 1988, ss. 32,93

Aslanapa, O., Türk Sanatı 1. İstanbul: MEB, 1972, ss. 19-24,39-40, $52,53,55,59,60,61,101,106$.

Aslanapa, O., Türk Sanatı 2. İstanbul: MEB, 1973.

Atlı, M., "Türkiye'de Cami Mimarlığı Tartışması Nerelerde Tıkanıyor? Kubbeyi Yere ve/veya Çamlıca Tepesi'ne Koymak", Inşaat Ya Resulullah (içinde), İstanbul: İletişim Yayınları, 2016, ss. 55-76.

Arpacıoğlu, Başak. , Camii Sembolizmi Üzerine Bir Deneme. Yeni Yüksektepe Dergisi, 2006, 53, ss. 36-50

Cantay, G., Türk Mimarisinde Külliye. HC Güzel, K. Çiçek ve S. Koca (Der.), Türkler Ansiklopedisi içinde, 2002, 7, ss. 836-853. 
Demirci, M., İslam'da Şehir ve Şehrin Sosyal Dinamikleri. İstem, 2003, (2), ss. 129-146. Güzer, C. A., Modernizmin Gelenekle Uzlaşma Çabası Olarak Cami Mimarlığı. Mimarlık Dergisi, 2009, (348), ss. 21-23.

Hasol, D., Ansiklopedik Mimarlık Sözlüğü (11. Baskı). İstanbul: Yem Yayınları, 2010, SS. 105.

Kurniawan, H., "Familiarity in Designing a Mosque: A Practice of Universal Design", Tokyo World Congress Programme Work Programme - Architecture for All Regions I, II, III \& IV.,2011.

Longhurst, C. E., Theology of a Mosque: The Sacred Inspiring Form, Function and Design in Islamic Architecture. Lonaard Journal, 2012, 2(8), ss. 2045 - 8150.

Ramazanoğlu, M. G. 16 Yüzyılda Osmanlı Külliyeleri. Çukurova Üniversitesi Sosyal Bilimler Enstitüsü Dergisi, 2008, 17(3), ss. 333-344.

Vehbi, Ü., İslam'da İbadetlerin Sosyal Fonksiyonu. Cumhuriyet Üniversitesi Ilahiyat Fakültesi. 2010.

Yavuzer, H., Diyanet İşleri Başkanlığının Kurumsal Yapılanması İçinde Cami Hizmetlerine Sosyolojik Bir Bakış. Sosyal Bilimler Araştırma Dergisi (Sbard), 2008, 12, ss. $175-199$.

Url-1:https://cdn.islamansiklopedisi.org.tr/dosya/26/C26008675.pdf (Erişim Tarihi 04.03.2020).

Url-2: T.C. Diyanet İşleri Başkanlığı Genelgesi, 2007, Ek 95 "Yurt Genelinde Yapılacak Cami Projelerinde Bulunması Gereken Asgari Unsurlar ve Müştemilatlar". Erişim Linki https://hukukmusavirligi.diyanet.gov.tr/Documents/2007\%20Genelgesi\%20EKLER\%C4 \%B0.pdf Erişim Tarihi: 02.02.2020.

Url-3: Çinici, B., "Dinde bir devrimin geçirilmemesi, caminin kare tabanlı, merkezi ve yuvarlak kubbeli olarak sürmesinin nedenidir" 2008, http://www.mimarizm.com/makale/behruz-cinici-dinde-bir-devrimin-gecirilmemesicaminin-kare-tabanli-merkezi-ve-yuvarlak-kubbeli-olarak-surmesininnedenidir_113523?sourceld=113506, (Erişim Tarihi: 28.01.2018).

Url-4: Tanyeli, U., "Karakaş Cami, kubbeyi tüm altyapısından koparmak, ama yine de Osmanlı'nın tüm anılarını kullanmak şeklindeki riyakârlığı mahkûm ediyor", 2008, http://www.mimarizm.com/haberler/dini-hayatin-estetik-dunyasini-daraltan-zamanecamileri-mercek-altinda_117356?sourceld=113506, (Erişim Tarihi:: 28.01.2018).

Url-5: http://seyahat.mynet.com/mimarisiyle-buyuleyen-camiler-1185822 (Erişim Tarihi 04.03.2020).

Url-6: https://www.haberturk.com/gundem/haber/1212385-istanbulun-siradisi-camileri/5 (Erişim Tarihi 04.03.2020).

Url-7: $\quad$ http://www.enderinsaat.com/m/projedetay-13-ahmet-hamdi-akseki-camii.html (Erişim Tarihi: 02.02.2020). 